Tạp chí Khoa học và Công nghệ biển T11 (2011). Số 3. Tr 71 - 83

\title{
INDIVIDUAL VARIATION OF TOXICITY IN THREE VIETNAMESE TOXIC MARINE PUFFER SPECIES
}

\author{
DAO VIET HA \\ Institute of Oceanography, Vietnam
}

SHIGERU SATO

School of Marine Bioscience, Kitasato University, Japan

\begin{abstract}
Summary: In Vietnam, several poisonings due to consumption of marine puffers have been reported every year for a long time, even recently. In most cases, the causative species were those commonly found in Vietnam were Torquigener gloerfelti, Takifugu oblongtus and Lagocephalus sceleratus. In this study, the toxicity of various organs (skin, muscle, intestine, liver and gonad) was analyzed by High Performance Liquid Chromatography (HPLC) in several specimens of above-mentioned three species which were collected from the Khanh Hoa coastal waters in 2007 and 2008. High variation was observed in the toxicity of the organs of each species. The gonad and the liver showed the highest toxicity, in terms of high average toxicity as well as large toxicity range: the toxicity of the gonad of $T$. gloerfelti was $123.2 \pm 240.6 \mathrm{MU} / \mathrm{g}$; that of the liver of $\mathrm{T}$. oblongtus was $171 \pm 239.3 \mathrm{MU} / \mathrm{g}(\mathrm{n}=30)$. Especially, the muscle of L. sceleratus often showed quite high toxicity $(58.7 \pm 62.3 \mathrm{MU} / \mathrm{g}$, $n=12)$ which is dangerous for human consumption. $83 \%$ of the specimens of this species showed the toxicity higher than safety consumption level suggested in Japan (10 MU/g). These results show that these puffer species are inappropriate for food because of high level of toxin, though some nontoxic or weakly toxic specimens are included.
\end{abstract}

\section{INTRODUCTION}

In the last decade, the poisoning caused by consumption of puffer accounted for $15.1 \%$ of all the food poisonings in Vietnam. The estimated number of the victims was 737 peoples with 127 mortalities during 1999 - 2003. It is most remarkable that puffer poisoning scored high, and is characterized by high mortalities. The mortalities by puffer poisoning were accounted for $17.2 \%$ of puffer poisonings and for $42.9 \%$ of total mortalities by food poisonings (Tran et al., 2005). Marine puffers are usually not used as food. However, sometimes puffers were used as materials for making fish sauce together 
with other small fish. Local people believe that the toxin disappears during fermentative process of fish sauce.

Among more than 40 marine puffer species found in Vietnamese coastal waters, some of them were considered as causative species for food poisoning in Vietnam such as Torquigener gloerfelti, Takifugu oblongtus, Lagocephalus lunaris, L. sceleratus, and L. suezensis (Vo et al., 2004). Dangerously, some considerably highly toxic species as $L$. lunaris (Dao unpubl., 2004) were listed as economic species in Vietnam, due to their high catching production (100-200 tones/year) (Nguyen 1999).

To keep seafood sanitation, puffer fish collected in Vietnam have to be examined systematically. This study was presented toxicity data on in three common puffer species in Vietnam.

\section{MATERIALS AND METHODS}

\section{Specimens of puffers}

Three common species of puffers, T. oblongtus, T. gloerfelti and L. sceleratus (Fig. 1) were collected from local fish landing areas (Cua Be, Van Ninh) in Khanh Hoa Province (Fig. 2) during the year 2007 (Table 1). The specimens were immediately carried to the Laboratory of Department of Biochemistry, Institute of Oceanography, Nha Trang, Vietnam in ice-cold condition.

Table 1: Puffer specimens collected in Khanh Hoa province in 2007

\begin{tabular}{|c|c|c|c|c|c|}
\hline Species & $\begin{array}{c}\text { Date of } \\
\text { sampling }\end{array}$ & $\begin{array}{c}\text { Sampling } \\
\text { location }\end{array}$ & $\begin{array}{c}\text { No. of } \\
\text { specimens }\end{array}$ & $\begin{array}{c}\text { Body weight (g) } \\
\text { Mean } \pm \text { SD }\end{array}$ & $\begin{array}{c}\text { Body length (cm) } \\
\text { Mean } \pm \text { SD }\end{array}$ \\
\hline $\begin{array}{c}\text { Takifugu } \\
\text { oblongtus }\end{array}$ & Aug, 07 & Van Ninh & 9 & $87.8 \pm 22.4$ & $15.9 \pm 1.3$ \\
\hline Torquigener & Mar-May, 07 & Cua Be & 30 & $177.5 \pm 98.7$ & $19.3 \pm 3.3$ \\
\hline gloerfelti & Aug - Sep, 07 & Van Ninh & 30 & $175.9 \pm 52.7$ & $19.1 \pm 1.8$ \\
\hline L. sceleratus & July - Sep, 07 & Van Ninh & 12 & $295.6 \pm 209.1$ & $26.39 \pm 6.50$ \\
\hline
\end{tabular}

${ }^{1}$ Van Ninh: Fish port in Van Ninh district, Khanh Hoa province $(60 \mathrm{~km}$ north from Nha Trang city); ${ }^{2} \mathrm{Cua}$ Be: Fish port in Nha Trang city 
(a)

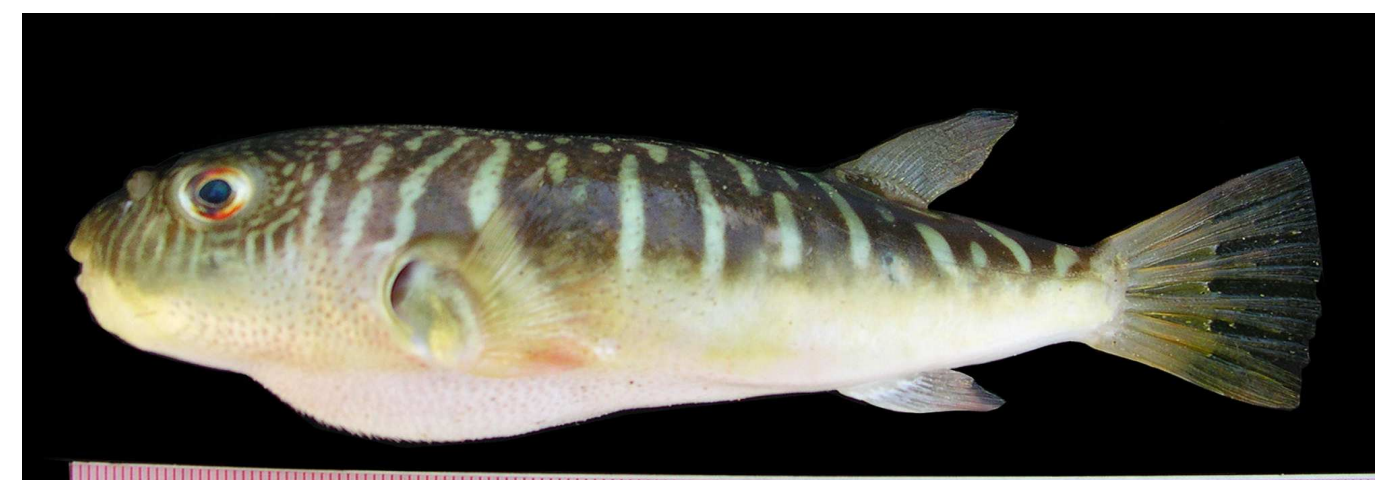

|

(b)

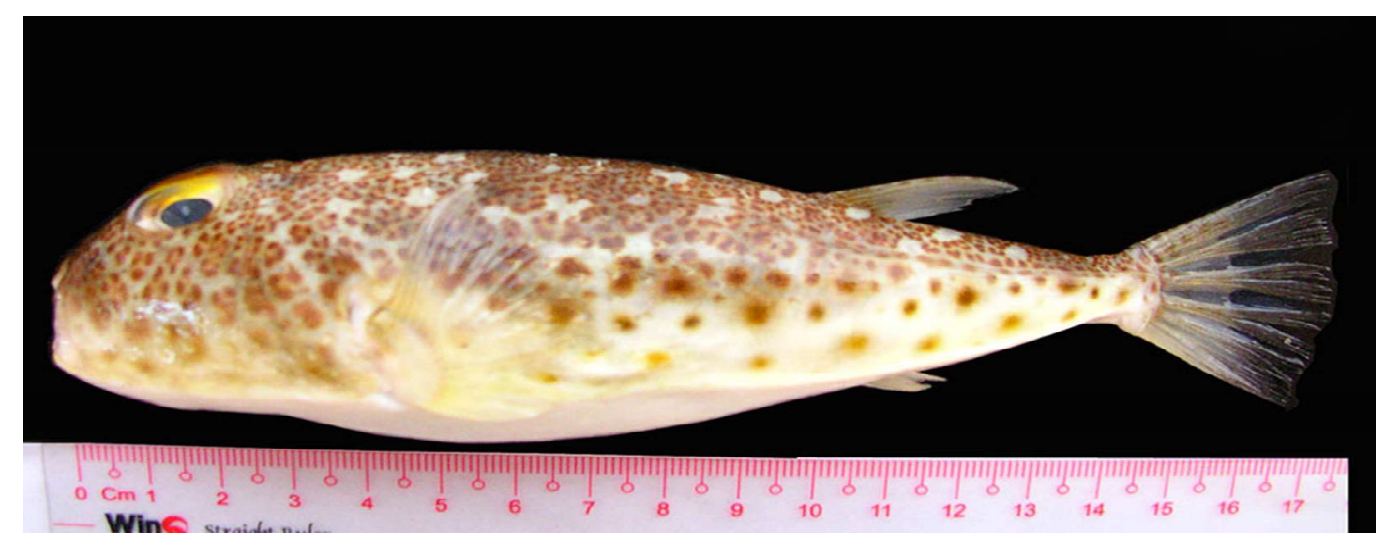

(c)

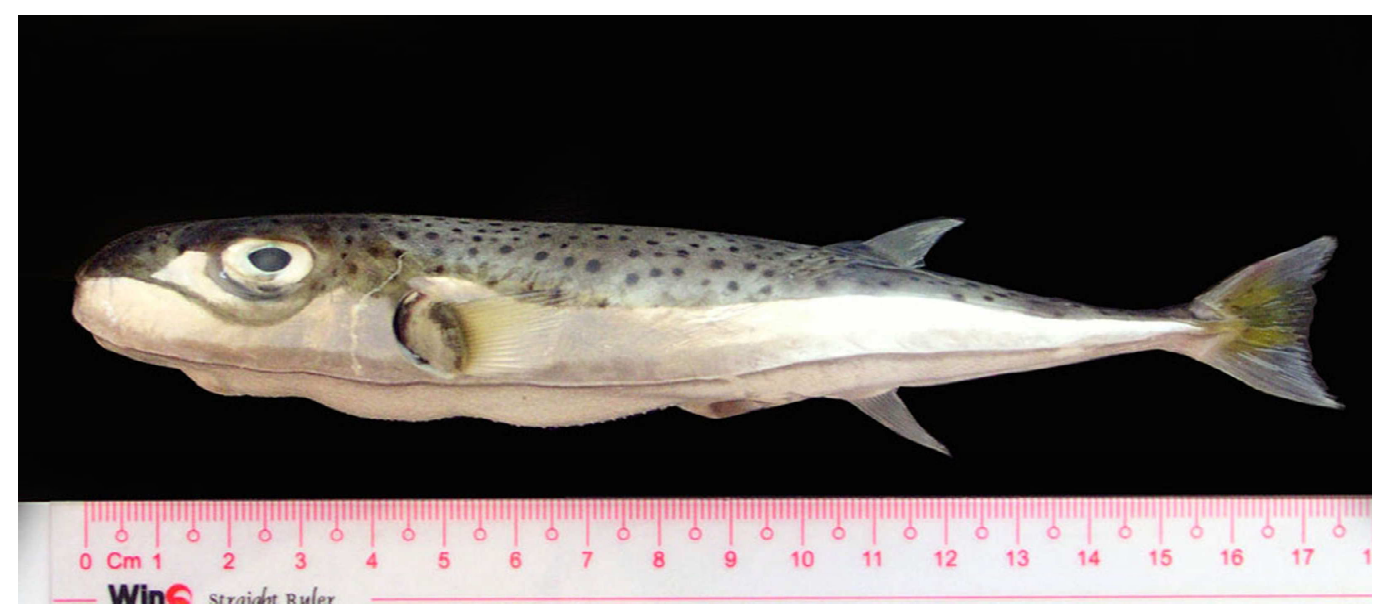

Figure 1: Three species of puffers used in the study (a) Takifugu oblongtus, (b) Torquigerner gloerfelti, (c) Lagecephalus sceleratus 


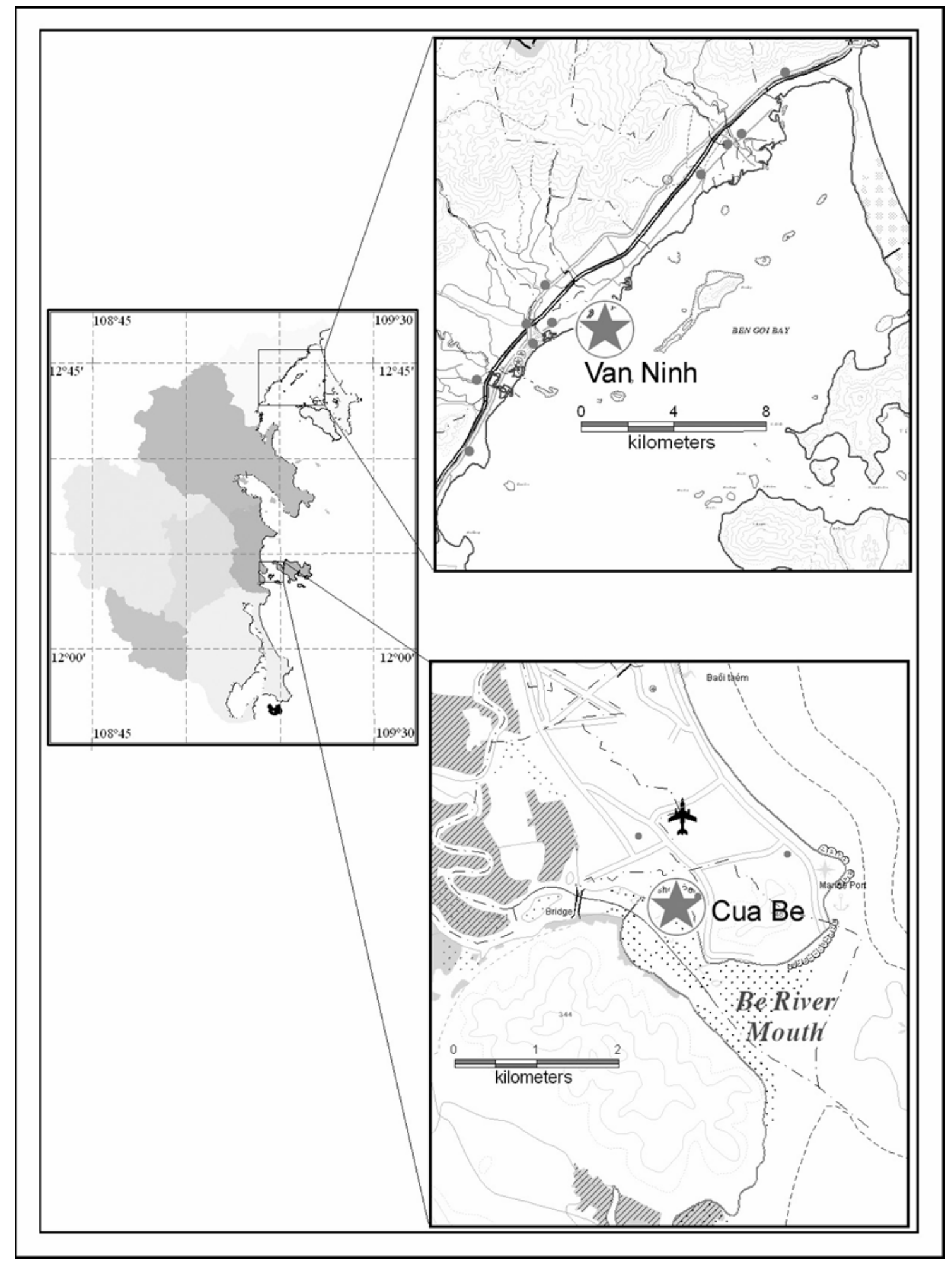

Figure 2: Van Ninh and Cua Be ports, Khanh Hoa province- Sampling places for puffers 


\section{Extraction and HPLC analysis for individual toxicity variation}

Puffer specimens were dissected into the skin, meat, liver, intestine and gonad (ovary or testis). The tissue of each organ from each fish was homogenized and extracted with an equal volume of $1 \%$ acetic acid $(1 \mathrm{~g}: 1 \mathrm{~mL})$, and boiled for 5 minutes. After being cooled down to room temperature, the homogenate was messed up to twice volume of the organ with $1 \%$ acetic acid. Then the mixture was centrifuged to get the supernatant, of which $1 \mathrm{~mL}$ is equivalent to $0.5 \mathrm{~g}$ of organ. These extracts were analyzed by a Fluorometric High Peformance Liquid Chromatography (HPLC) analyzer for TTX (Yotsu et al. 1989) and PSP toxins (Oshima, 1995). Authentic standard of TTXs (TTX, 4-epiTTX and 4,6-anhTTX mixture) was prepared from the toxic liver of a Japanese puffer Takifugu paradalis (Kodama and Ogata, 1984). Standard PSP toxins (C1+C2 mixture, GTX1-4 mixture, STX, dcSTX and neoSTX mixture) are a gift from Dr. Oshima, Tohoku University. The toxicity was calculated based on the specific toxicity of each TTX component and expressed in mouse unit (MU) (Nakamura and Yasumoto, 1985). One MU is a toxin dose which kills a 20-g male mouse (ddY strain) in $30 \mathrm{~min}$.

\section{Data analysis}

The distribution of toxicity in different organs of puffers was analyzed in excel software, the significant difference of toxicity among different batch samples was tested by t-test.

\section{RESULTS}

\section{Toxin component}

Fig. 3 shows an example of HPLC chromatograms obtained from a meat extract of T. gloerfelti. Both TTX and STX were detected in most of the specimens with some exceptions of $T$. gloerfelti specimens. 4epi-TTX and Anhydro-TTX as well as neo-STX and dc-STX were also detected in almost puffer extracts.

Fig 4 summarizes the average mol \% of TTX toxins to total toxins (STXs and TTXs) of each organ of puffer species T. gloerfelti $(n=30)$. Ratio of TTX toxins was accounted about $95-98 \%$ of total toxins in all organs. The same toxin proportion was found in the extracts of $T$. oblongtus and L. sceleratus (data not showed). The present data in combination with preliminary studies on toxin in puffers from Vietnam in previous years (Dao unpubl., 2004) indicated that TTX was the main toxin component in puffers from Vietnam. 


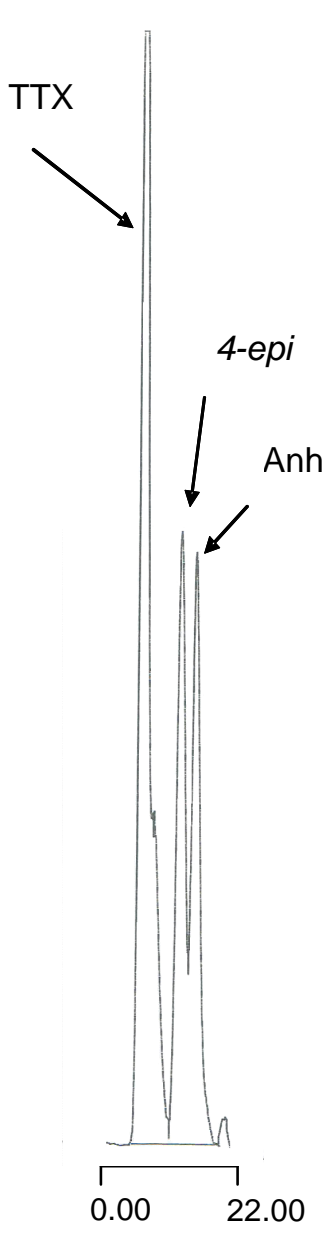

TTXs standard

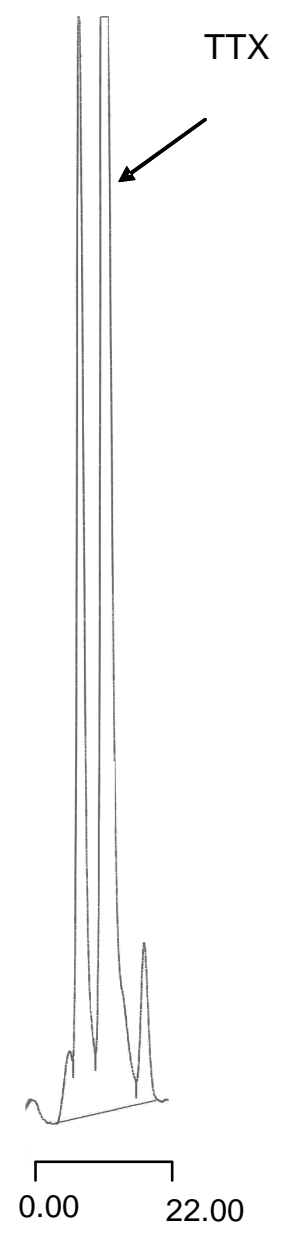

Extract from meat of $T$. gloerfelti

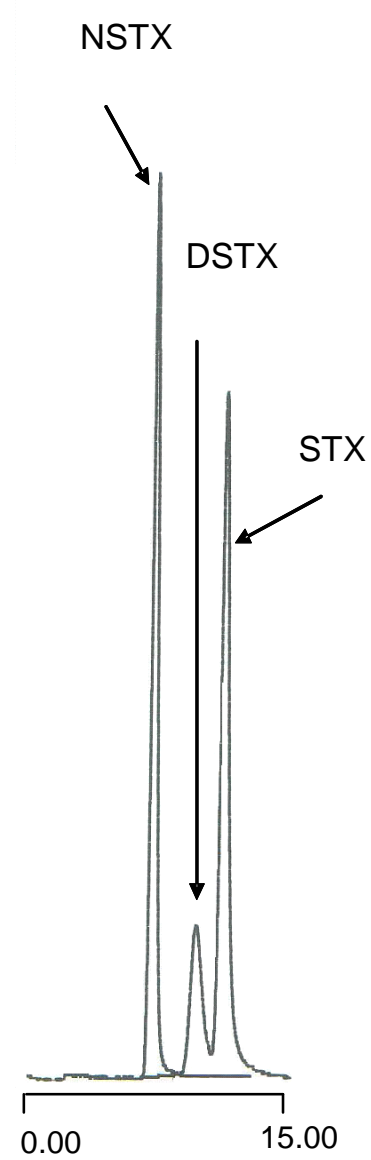

STXs standard

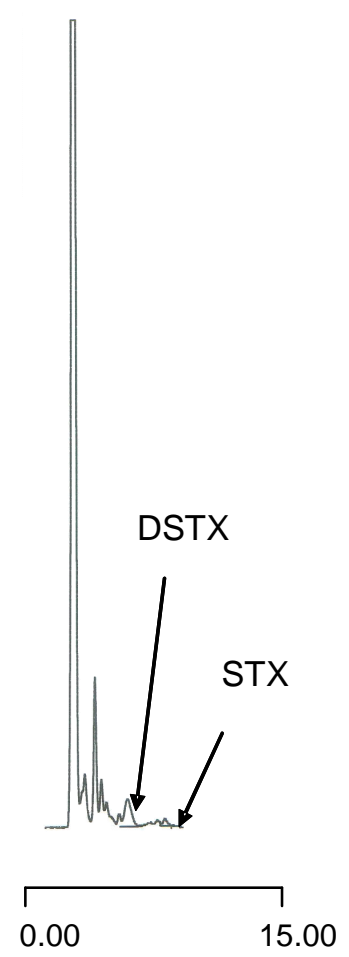

Extract from meat of $T$. gloerfelti

Figure 3: HPLC chromatograms of a meat extract of $T$. gloerfelti

\section{Individual variation of toxicity}

Based on toxin composition in Vietnamese puffers, in which main toxin component is TTX, in this subject we ignored minor amount of toxicity from PSP toxins of these specimens. Table 2 shows the average toxicity of the extracts from different organs of each specimen in each species. In each organ, toxicity showed remarkable significant difference with very large range among individuals in every species (Fig 5). In $T$. oblongtus, maximum toxicity was found in the liver $(702.4 \mathrm{MU} / \mathrm{g})$, while in $T$. gloerfelti, it was found in the gonad $(977.9 \mathrm{MU} / \mathrm{g})$. The extracts from meat of three species were found to be toxic at different levels. Meat of L. sceletatus was the highly toxic (58.7 \pm 62.3 
MU/g; range: 3.8 - $213 \mathrm{MU} / \mathrm{g}$ ) and $83 \%$ of the specimens contains TTX over $10 \mathrm{MU} / \mathrm{g}$. In contrast, meat of $T$. oblongtus and $T$. gloerfelti seems to be less toxic with lower frequency of toxic specimens (Table 3). Among different organs of these puffer species, meat often showed lowest toxicity, skin was the second low followed by the intestine, while the liver and the gonad always showed high toxicity (Fig. 5). However, maximum toxicity in their meat, especially the meat of L. sceleratus, was far beyond the safety limit for puffer consumption in Japan (Kodama and Sato, 2005) (Table 2).

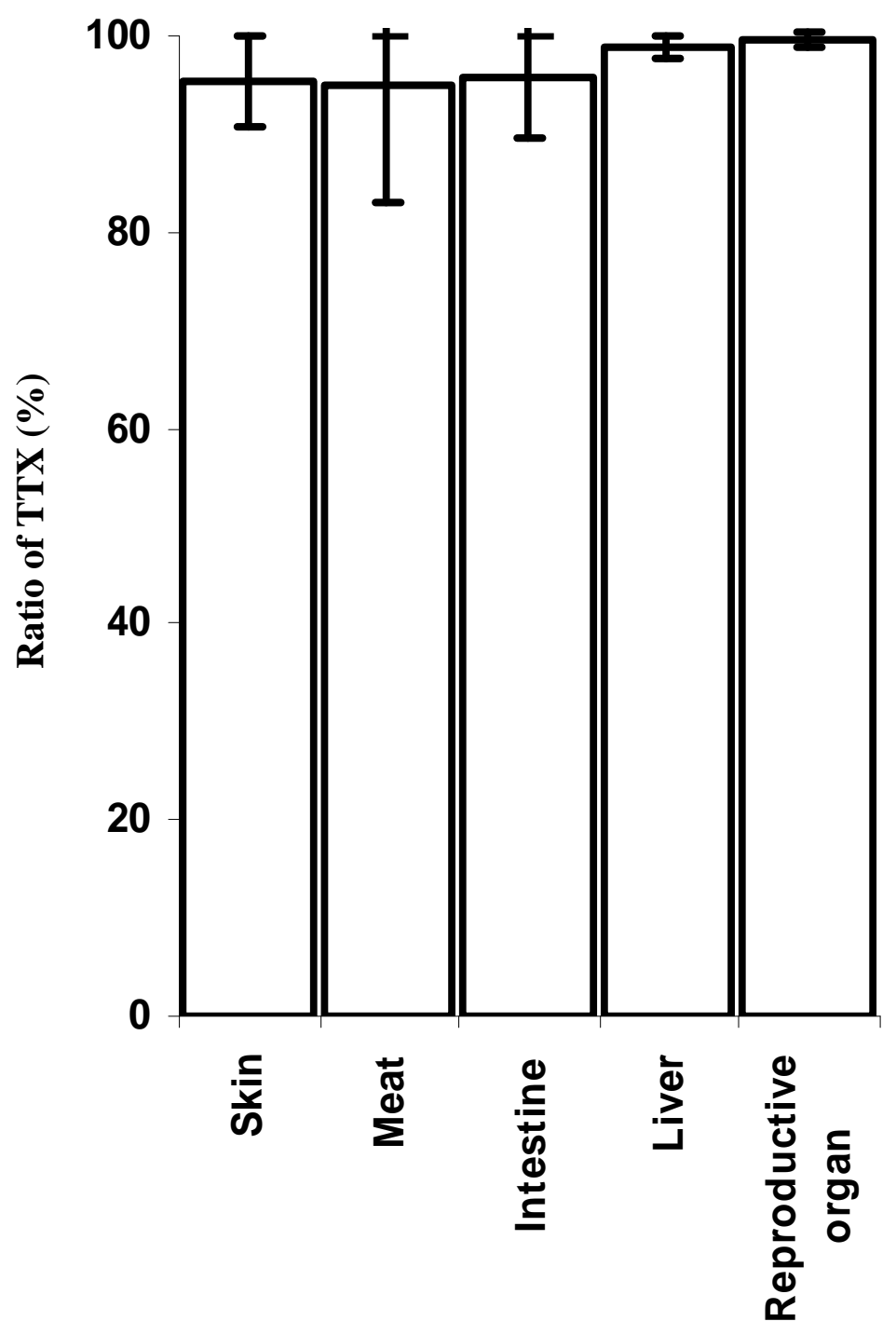

Figure 4: mol \% of TTXs to total toxins (TTXs + STXs) in each organ of puffer $T$. gloerfelti $(\mathrm{n}=30)$ 
In the skin, meat and intestine of $T$. gloerfelti, no significant difference of toxicity was observed between two sampling times in a year. In contrast, the liver and gonad of several specimens of T. gloerferti collected in Mar. - May 2007 showed much higher toxicity than those collected in August 2007. However, no significant difference was observed in the frequency of specimens, which showed toxicity higher than $10 \mathrm{MU} / \mathrm{g}$ in the liver and gonad in these two batch samples.

Table 2: Mean, SD and range of toxicity (MU/g) in each body organ of puffer species

\begin{tabular}{|c|c|c|c|c|c|c|c|c|c|c|c|}
\hline \multirow[b]{2}{*}{ Species } & \multirow{2}{*}{$\begin{array}{c}\text { Sampling } \\
\text { period }\end{array}$} & \multicolumn{2}{|c|}{ Skin } & \multicolumn{2}{|c|}{ Meat } & \multicolumn{2}{|c|}{ Intestine } & \multicolumn{2}{|c|}{ Liver } & \multicolumn{2}{|c|}{$\begin{array}{c}\text { Reproductive } \\
\text { organ }\end{array}$} \\
\hline & & $\begin{array}{l}\text { Mean } \\
\pm \mathrm{SD}\end{array}$ & Range & $\begin{array}{l}\text { Mean } \\
\pm \text { SD }\end{array}$ & Range & $\begin{array}{c}\text { Mean } \pm \\
\text { SD }\end{array}$ & Range & $\begin{array}{l}\text { Mean } \\
\pm \text { SD }\end{array}$ & Range & $\begin{array}{l}\text { Mean } \\
\pm \text { SD }\end{array}$ & Range \\
\hline $\begin{array}{c}T . \\
\text { oblongtus }\end{array}$ & Aug, 07 & $\begin{array}{c}22.4 \pm \\
12.7\end{array}$ & $\begin{array}{c}0- \\
40.1\end{array}$ & $\begin{array}{c}6.4 \pm \\
7.3\end{array}$ & $\begin{array}{c}0- \\
22.1\end{array}$ & $\begin{array}{c}98.4 \pm \\
93.0\end{array}$ & $\begin{array}{c}0- \\
221.8\end{array}$ & $\begin{array}{c}178.1 \\
\pm \\
239.3\end{array}$ & $\begin{array}{c}0- \\
702.4\end{array}$ & $\begin{array}{c}54.8 \pm \\
106.2\end{array}$ & $\begin{array}{c}0- \\
333.9\end{array}$ \\
\hline $\begin{array}{c}T . \\
\text { gloerfelti }\end{array}$ & $\begin{array}{c}\text { Mar-May, } \\
07\end{array}$ & $\begin{array}{c}14.0 \pm \\
14.0\end{array}$ & $\begin{array}{l}0.5- \\
53.9\end{array}$ & $\begin{array}{c}2.6 \pm \\
3.5\end{array}$ & $\begin{array}{c}0- \\
14.7\end{array}$ & $\begin{array}{c}11.1 \pm \\
13.2\end{array}$ & $\begin{array}{l}0.3- \\
54.5\end{array}$ & $\begin{array}{c}154.4 \\
\pm \\
200.8\end{array}$ & $\begin{array}{c}6.1- \\
782.3\end{array}$ & $\begin{array}{c}123.2 \\
\pm \\
240.6\end{array}$ & $\begin{array}{c}0- \\
977.9\end{array}$ \\
\hline & Aug, 07 & $\begin{array}{c}12.6 \\
\pm 13.9\end{array}$ & $\begin{array}{c}0- \\
52.3\end{array}$ & $\begin{array}{c}2.5 \\
\pm 3.6\end{array}$ & $\begin{array}{c}0- \\
14.6\end{array}$ & $\begin{array}{c}9.0 \\
\pm 11.2\end{array}$ & $\begin{array}{c}0- \\
36.5\end{array}$ & $\begin{array}{c}80.8 \pm \\
103.8\end{array}$ & $\begin{array}{l}3.6- \\
387\end{array}$ & $\begin{array}{c}62.3 \pm \\
109.5\end{array}$ & $\begin{array}{c}0- \\
458.7\end{array}$ \\
\hline $\begin{array}{c}\text { L. } \\
\text { sceleratus }\end{array}$ & $\begin{array}{c}\text { Jul-Sep. } \\
07\end{array}$ & $\begin{array}{c}27.8 \pm \\
20.6\end{array}$ & $\begin{array}{l}0.6- \\
59.1\end{array}$ & $\begin{array}{c}58.7 \pm \\
62.3\end{array}$ & $\begin{array}{l}3.8- \\
213\end{array}$ & $\begin{array}{c}119.8 \pm \\
163\end{array}$ & $\begin{array}{c}0.2- \\
559.1\end{array}$ & $\begin{array}{c}50.8 \pm \\
85.1\end{array}$ & $\begin{array}{c}0- \\
289.2\end{array}$ & $\mathrm{NT}^{*}$ & $\mathrm{NT}^{*}$ \\
\hline
\end{tabular}

$\mathrm{NT}^{*}$ : No sample to test

Table 3: Frequency (\%) of puffer specimen containing toxicity beyond consumption level for TTX suggested in Japan (10 MU/g)

\begin{tabular}{|l|c|c|c|c|c|c|c|}
\hline Species & Sampling time & $\mathbf{n}$ & Skin & Muscle & Intestine & Liver & Reproductive organ \\
\hline T. oblongtus & Aug, 07 & 9 & 78 & 22 & 89 & 89 & 56 \\
\hline T. gloerfelti & Mar.- April. 07 & 30 & 50 & 3 & 37 & 93 & 70 \\
\hline & Aug. 07 & 30 & 40 & 3 & 30 & 87 & 70 \\
\hline L. sceleratus & Jul.-Sep.,07 & 12 & 75 & 83 & 58 & 50 & NT* \\
\hline
\end{tabular}




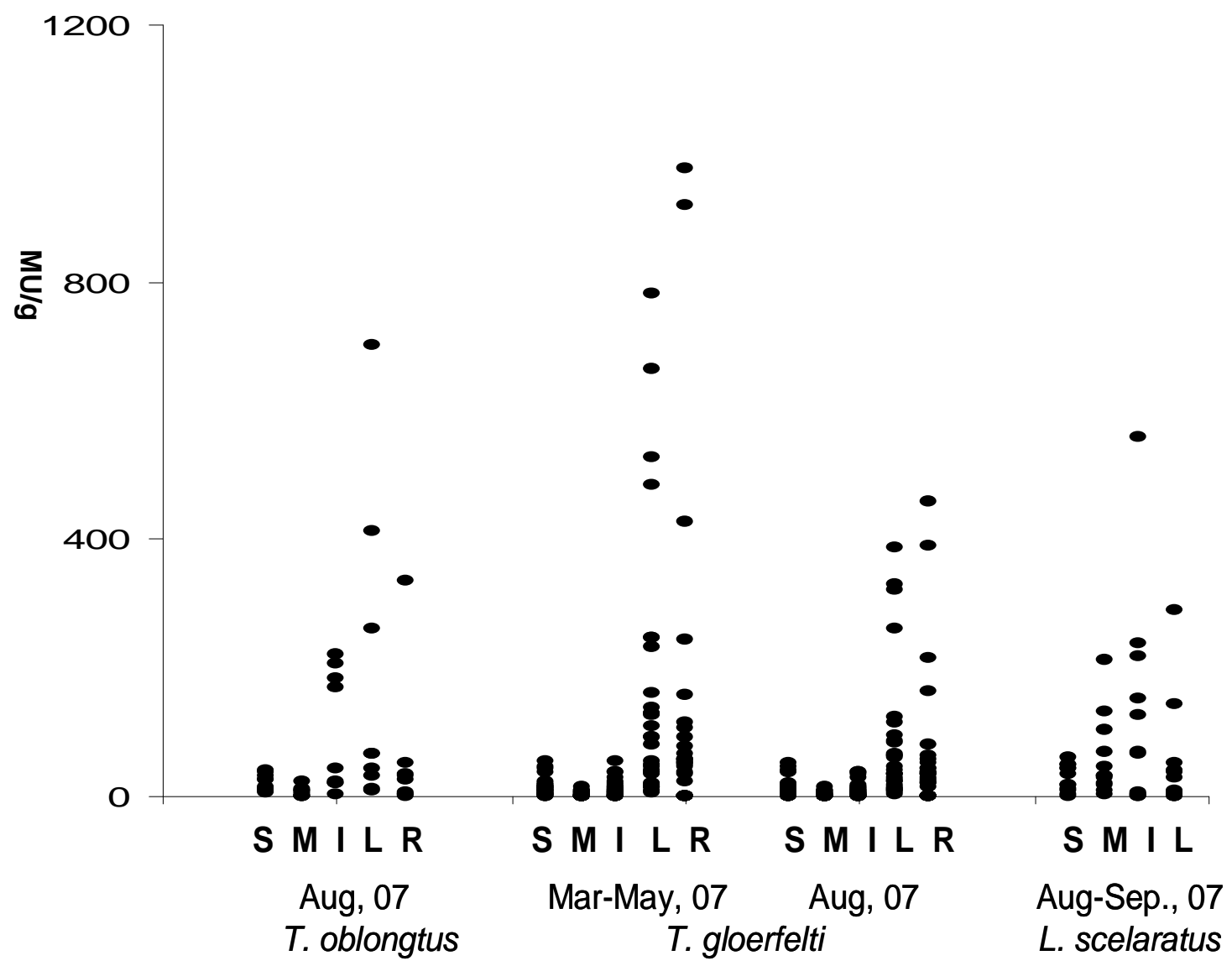

Figure 5: Toxicity distribution in various organs of three puffer species S: skin, M: meat, I: intestine, L: liver; R: reproductive organ (ovary/testis).

\section{DISCUSSION}

In the present study, TTX is always the main toxin component in puffers collected from Vietnam. TTX is also the main toxin component in Takifugu species collected in Japan (Kodama et al., 1984; Shiomi et al., 1985). On the other hand, the present data is different from some other studies, which reported STX was a major toxin component of some marine puffer species from the Philippines (Sato et al., 2000), freshwater puffers from Thailand (Kungsuwan et al., 1997, Sato et al., 1997), Bangladesh (Zaman et al., 1997). It is suggested that toxin component in puffers as well as other toxic organisms may have a close relation with living environment, though the origins of TTX as well as PSP toxins found in puffers are not clear yet. 
In June 2003, the Vietnamese government issued a strict ban for consumption of all of puffer species. However, because of poor living standard, lack of scientific information and public awareness, uncontrolled local markets, and lack of organized monitoring system on toxic puffers, fishermen communities still have processed puffers for food by themselves with several ways. They believe that it is safe to eat toxic puffer after some specific processings such as removing the skin and viscera, salty-drying or fermenting to make fish sauce. In Japan, the meat and skin of some Takifugu and Lagocephalus species are edible, because these parts are almost non-toxic. In contrast, it has been reported that puffer fishes such as L. lunaris collected in South China Sea (Hashimoto, 1979) and Arothron species collected in the Philippine (Sato et al., 2000) often showed high toxicity in their meat.

Specimens of three puffer species in this study showed a significant toxicity, comparable to some puffer species from other tropical countries such as Philippines (Sato et al., 2000), Thailand (Brillantes et al., 2003). Tendency of toxicity distribution among puffer body was also similar of that in puffers from Japan (Kodama et al., 1984), India (Ghosh et al., 2004) although toxicity of Vietnamese puffers seems to be less toxic than Japanese puffers (Kodama et al., 1984). However, TTX in the meat of L. sceleratus frequently beyond the safety level (10 MU/g), therefore, not only liver and ovary, but also meat of this species is quite dangerous for human consumption.

Ghosh et al. (2004) revealed that puffer ovaries and liver become higher toxic in mature period. Nevertheless, in this study, number of specimens is limited, and the ratio of toxic and nontoxic specimen is affected by the ratio of female and male, which was impossible to be identified by visual eyes, the difference may be due to very large individual variation of toxicity.

\section{CONCLUSION}

The results of survey on the toxins in three species marine puffers responsible for many poisonings in Vietnam revealed that they possess both TTX and STX, in which TTX is as dominant toxin of all poisoning cases. The toxicity in these species is different depending on individual and tissue. This finding shows that toxin component and toxicity of Vietnamese puffers are similar to other Asian tropical countries. However, because of limited sampling scale and time, the data of the present study do not show regional and seasonal toxicity variation in these species.

From public heath point of view, a special attention should be paid to the fact that significant toxicity level found in consumed organs such as the liver, gonad and meat. 
Together with very large individual variation of toxicity, these puffer species in Vietnam should be avoided to use as a food resource. Public awareness and education about potential risk from toxic puffers for local community should be paid more attention.

Acknowledgement: We would like to thank to Prof. Dr. Keichii Matsuura, National Museum of Nature and Science, Tokyo, Japan for correction of the scientific name of puffers and thank to Prof. Dr. Masaaki Kodama, School of Marine Bioscience, Kitasato University, Japan for revising the manuscript.

\section{REFERENCES}

1. Brillantes, S., W. Samosorn, S. Faknoi and T. Oshima, 2003. Toxicity of puffers landed and marketed in Thailand. Fisheries Science, 69: 1224-1230.

2. Ghosh, S., Hazra A. K., Banerjee S. and Mukheriee B., 2004. The seasonal toxicological profile of four puffer fish species collected along Bengal coast, India. Indian Journal of Marine Sciences, 33: 276-280.

3. Hashimoto, Y., 1979. Marine toxins and other bioactive marine substances. Japanese Scientific Society Press. 358pp.

4. Kodama M. and S. Sato., 2005. Puffer toxin. Shyokuhin Eiseikensasisin (The Manual for Food Sanitation Test). Ministry of Health, Labour and Welfare (ed.) Japanese Hygienic Association, Tokyo. 661-666 (In Japanese).

5. Kodama, M, T. Ogata, K. Kawamukai, Y. Oshima and T. Yasumoto., 1984. Toxicity of muscle and other organs of five species of puffer collected from the Pacific coast of Tohoku area of Japan. Bull Jap Soc Sci Fish. 50: 703-706.

6. Kunggsuwan, A., O. Arakawa, M. Promdet and Y. Onoue., 1997. Occurrence of paralytic shellfish poisons in Thai freshwater puffers. Toxicon 53 (8): 1341-1346.

7. Nakamura, M. and Yasumoto T., 1985. Tetrodotoxin derivatives in puffer fish. Toxicon 23: 271-276.

8. Nguyen, H.P., 1999. List of marine fishes in Vietnam. National Agriculture Publisher.

9. Noguchi, T., O. Arakawa and T. Takatani., 2005. TTX accumulation in puffer fish. Comparative Biochemistry and Physiology, Part D 1: 145-152. 
10. Sato, S., M. Kodama, T. Ogata, K. Saitanu, M. Furuya and K. Hirayama, 1997. Saxitoxin as a toxic principle of a freshwater puffer, Tetraodon fangi, in Thailand. Toxicon 35: 137-140.

11. Sato, S., T. Ogata, V. Boria, C. Gonzales, Y. Fukuyo and M. Kodama, 2000. Frequent occurrence of paralytic shellfish poisoning toxins as dominant toxins in marine puffer from tropical water. Toxicon, 38: 1101-1109.

12. Suekane, T. and S. Yagi, 1970. Experimental studies on globe fish poison (1) seasonal variation of the concentration, distribution in the fish body; and the stability of the poison. Yamaguchi Daigaku Nougakubu Gakujutsuhoukoku (Bull. Fac. Agr. Yamaguchi Univ.). 21: 1-19.

13. Tran D., T.C. Nguyen, H.D. Nguyen, T.P. Nguyen, M.K. Nguyen, V.P. Tran, T. K. Pham, T.H.H. Tran, H.P. Nguyen, V.H. Dao, M.S. Truong, T.S. Nguyen and V.T. Ngo, 2005. Investigation of influent factors and model of controlling to puffer poisonings. Scientific report of the Department of Food Sanitation and Safety, Vietnamese Ministry of Health (In Vietnamese).

14. Vo, S.T., H.P. Nguyen, T.N. Do and V.H. Dao, 2004. The investigation and study on toxic animals may cause human fatalities in Vietnamese coastal waters. Scientific report of Institute of Vietnamese Academic Sciences and Technology.

15. Yotsu, M., A. Endo and T. Yasumoto, 1989. Short communication: An improved tetrodotoxin analyser. Agric. Biol. Chem. 53 (3): 893-895.

16. Yu, C.-F. and P.H.-F. Yu, 2002. Are puffer fish more toxic in their spawning seasons? Marine Biology, 140: 1053-1057.

17. Yu, C.-F. and P.H.-F. Yu, 2002. The annual toxicological profile of two common puffer fish, Takifugu niphobles (Jordan and Snyder) and Takifugu alboplumbeus (Richardson), collected along Hong Kong coastal waters. Toxicon 40: 313-316.

18. Zaman, L., O. Arakawa and A. Shimos (1997). Occurrence of paralytic shellfish poisoning in Bangladeshi freshwater puffer. Toxicon 35 (3): 423-431. 


\title{
BIẾN ĐỘNG ĐộC TÍNH THEO CÁ THỂ CỦA BA LOÀI CÁ NÓC ĐỘC BIỂN VIÊT NAM
}

\author{
ĐÀO VIỆT HÀ, SHIGERU SATO
}

Tóm tắt: Rất nhiều vu ngộ độc do tiêu thu cá nóc biển đã đuợc ghi nhận hàng năm tại Việt Nam. Một số loài cá nóc thuờng gặp nhu cá nóc Chấm Cam Torquigener gloerfelti, cá nóc Vằn Takifugu oblongtus và cá nóc Đầu thỏ chấm tròn Lagocephalus sceleratus được xác định là đối tuợng gây ra hầu hết các vu ngộ độc này. Trong nghiên cứu này, độc tính của các bộ phận co thể khác nhau (da, thịt, nội quan, gan và trúng/tinh sào) của ba loài cá nóc trên thu tại vùng biển Khánh Hòa trong năm 2007 và 2008 đuợc phân tích bằng phuong pháp sắc ký lỏng hiệu năng cao. Khoảng dao động rộng của độc tính được ghi nhận ở tất cả các bộ phận co thể của cả ba loài nghiên cúu. Trứng/tinh sào và gan có độc tính trung bình cao nhất và khoảng dao động độc tính rộng nhất. Ở loài cá nóc Chấm cam, độc tính trong trứng/tinh sào là $123.2 \pm 240.6 \mathrm{MU} / \mathrm{g}$; trong gan là $171 \pm 239.3 \mathrm{MU} / \mathrm{g}(n=30)$. Đặc biệt, phần co (thịt) của loài cá nóc Đầu thỏ chấm tròn có độc tính cao khá cao $(58.7 \pm 62.3 \mathrm{MU} / \mathrm{g}, n=12)$, nguy hiểm cho người tiêu dùng. Mặt khác, $83 \%$ mẫu vật cá nóc Đầu thỏ chấm tròn biểu hiện độc tính cao hơn giá trị an toàn tiêu dùng đề xuất tại Nhật Bản $(10 \mathrm{MU} / \mathrm{g})$. Kết quả nghiên cứu cho thấy tất cả các bộ phận cơ thể của ba loài cá nóc trong nghiên cứu này không thích hợp sử dụng làm thực phẩm, mặc dù một vài cá thể không độc hay có độc tính yếu.

Ngày nhận bài: 25 - 7 - 2010

Ngườ nhận xét: TS. Phạm Xuân Kỳ 